\title{
Tumor Lysis Syndrome, CTCAE 5.0
}

National Cancer Institute

\section{Source}

National Cancer Institute. Tumor Lysis Syndrome, CT CAE 5.0. NCI Thesaurus. Code C146688.

A disorder characterized by metabolic abnormalities that result from a spontaneous or therapy-related cytolysis of tumor cells. 